\title{
Jan Andrzej Sierakowski i jego „Konnotata prywatne”
}

ABSTRAKт: Zasadniczą częścią artykułu jest edycja krótkiego dziełka pamiętnikarskiego z drugiej połowy XVII w., należącego niewątpliwie do gatunku rodzinnych raptularzy, popularnych zwłaszcza w piśmiennictwie szlacheckim XVII-XVIII w. Tekst pióra Jana Andrzeja Sierakowskiego (zm. 1698 r.) jest rzeczowym i lapidarnym zapisem wydarzeń z lat 1664-1697, przede wszystkim prywatnych i rodzinnych, dotyczących także działalności publicznej autora, również jego rozlicznych transakcji, głównie natury majątkowej. Raptularz wydaje się interesującym świadectwem szlacheckiego żywota i codzienności. Edycję poprzedza krótki wywód historii rodu Sierakowskich, w głównej mierze zaś autora owego tekstu.

sŁowa KLuczowe: pamiętnikarstwo, Jan Andrzej Sierakowski, historia Polski XVII w.

Prezentowany poniżej tekst krótkiego pamiętnika z drugiej połowy XVII w. spisał Jan Andrzej Sierakowski herbu Dołęga, szlachcic związany z województwami bełskim i lubelskim, wieloletni żołnierz i rotmistrz królewski, który w końcowych latach życia sprawował senatorską już godność kasztelana bełskiego. Zapiski opatrzone tytułem „Pewne konnotata prywatne domowych transakcyjej moich” obejmują niemal całe dorosłe życie autora, od ukończenia nauki szkolnej i początków służby publicznej w 1664 r. do pierwszych miesięcy 1697 r. Sierakowski prowadził jednak swoje zapiski także później, o czym świadczy jeszcze inny jego tekst zatytułowany „Konnotata różnych transakcyjej w Polszcze”. Ostatnie informacje 
tam zawarte dotyczą wydarzeń z lipca 1698 r., wyprzedzających o kilka miesięcy nagłą śmierć autora, która nastąpiła we Lwowie 7 XII 1698 r. $^{50}$

Na treść niezbyt obszernego dziełka Sierakowskiego składają się z reguły lapidarne i rzeczowe, zgodnie $\mathrm{z}$ diariuszowym schematem, w bardzo wielu wypadkach dokładnie datowane zapisy, dotyczące najważniejszych - w przekonaniu autora - wydarzeń przede wszystkim z jego własnego życia tak rodzinnego, jak i prywatnego. Przyszły kasztelan skrupulatnie notuje wiadomości o narodzinach i zgonach potomstwa, podobnych zdarzeniach spotykających inne osoby, szczególnie jednak $\mathrm{z}$ kręgu rodziny i znajomych, $\mathrm{z}$ którymi był zapewne powiązany lub pozostawał w jakiejś bliższej zażyłości. Nie zapomina o epizodach osobistej kariery urzędniczej, zwłaszcza wojskowej. Czasem pisze o innych dotyczących rodziny przypadkach, szczególnie, jak można sądzić, tych niezwyczajnych. $\mathrm{Z}$ widoczną sumiennością odnotowuje również swoje ważniejsze poczynania majątkowe, różnorodne transakcje, dzierżawy, zastawy, zaciągane długi, pożyczki itp. Spisując „Konnotaty”, kieruje się zatem ich praktyczną, codzienną wręcz przydatnością. Nie stroni od przekazywania informacji o wydarzeniach mających donioślejsze znaczenie, wykraczających poza potrzebę opisu ściśle indywidualnego żywota. Nie brakuje zatem wieści o zdarzeniach z życia publicznego, politycznego czy wojskowo-militarnego. Wzmianki o takich sprawach są wprawdzie bezosobowe i jak całe dzieło zwięzłe, chociaż na ogół nie mamy wątpliwości - czy niekiedy wręcz jesteśmy pewni - że Sierakowski pisze zwłaszcza o tym, czego był świadkiem lub o czym usłyszał, o wydarzeniach, których był czynnym uczestnikiem, niekiedy całkiem znaczącym, choć niekoniecznie pierwszoplanowym aktorem. „Konnotaty” powstawały zapewne na bieżąco. Kolejne wpisy pojawiały się raczej bezpośrednio lub wkrótce po wydarzeniach, co niewątpliwie wzmacnia ich wiarygodność. Sierakowski pisze lakonicznie, w sposób wolny od ocen. Nie ma w jego dziele miejsca na obszerniejsze i bardziej szczegółowe opisy zdarzeń, wyraźnie unika osobistych uwag, refleksji i komentarzy. Tylko wyjątkowo, czasami wręcz jedno słowo sugeruje, że autorowi mogły towarzyszyć jakiekolwiek emocje. Z pewnością pisał po to, aby utrwalić ważniejsze daty i wydarzenia z własnego życia, może niekiedy towarzyszyła mu myśl o przekazaniu tej wiedzy, budującej wszakże tradycję rodu, swoim następcom. „Konnotaty” doskonale zatem wpisują się w schemat rodzinno-rodowego raptularza, dobrze znanego także z innych przykładów, gatunku pisarskiego

${ }^{50}$ E. Janas, Sierakowski Jan Andrzej, [w:] Polski Słownik Biograficzny (dalej PSB). T. 37, 1996, s. 266-267; J. Korendowicz do S. Szczuki, Lwów, 8 XII 1698, Archiwum Główne Akt Dawnych, Archiwum Publiczne Potockich, 163a, s. 612-613. 
dosyć popularnego w sarmackiej epoce. Należy dodać, że nie mają one specjalnie oryginalnego charakteru, nie ujawniają istotnych, nieznanych wcześniej faktów czy przejawów szlacheckiej codzienności. Są natomiast jeszcze jednym interesującym świadectwem dosyć przeciętnego żywota osoby i rodziny należących do społecznej elity.

Sierakowscy herbu Dołęga, piszący się ze Starego Sierakowa, wywodzili się z ziemi gostyńskiej na Mazowszu, ale zamieszkiwali również na ziemiach czerskiej i stężyckiej. Na Lubelszczyźnie pojawili się zapewne dopiero w XVI w. Pierwszym wyraźniej zapisanym w historii tego regionu przedstawicielem rodu był Wojciech Sierakowski, wedle niektórych genealogów używający wszakże herbu Lubicz, co jednak nie jest całkiem pewne. Wojciech od schyłku XVI w. pełnił przez ponad dwadzieścia lat urząd pisarza grodzkiego lubelskiego, w czasach gdy starostwo pozostawało w rękach Jana i Mikołaja Firlejów. Musiał się cieszyć sporym autorytetem obywateli swego województwa, skoro już w 1597 r. był kandydatem szlachty do godności pisarza ziemskiego, a w $1601 \mathrm{r}$. także podsędka. Nominacji na te urzędy jednak nie uzyskał. Pisarzem ziemskim lubelskim został dopiero w $1618 \mathrm{r}$. i pełnił tę funkcję do śmierci w 1626 r. Bywał ponadto poborcą podatków i marszałkiem sejmików w 1614 i 1622 r. Zgromadził (także za sprawą żony Katarzyny) skromny majątek, na który składały się m.in. części wsi Wronów, Dobre i Pankraczewice oraz wójtostwo w podlubelskim Wrotkowie i pewne grunta na Czwartku w samym Lublinie $^{51}$.

Niektóre z majątków Wojciecha przeszły w późniejszych latach w ręce Andrzeja Sierakowskiego, co mogłoby sugerować ich bliski związek krewniaczy ${ }^{52}$, na co jednak nie ma mocnych dowodów. Kariera tego kolejnego Sierakowskiego od początku przebiegała pod znakiem Marsa. Służbę wojskową Andrzej rozpoczął być może podczas kampanii chocimskiej w 1621 r. Kilka lat później, jako towarzysz wojska koronnego, walczył w wojnie o ujście Wisły na Pomorzu. Po jej zakończeniu w 1629 r. na czele roty kozackiej przyjął służbę cesarską i wojował w Rzeszy Niemieckiej. Do kraju powrócił w 1632 r., by na czele oddziału rajtarii wziąć udział w wojnie smoleńskiej, podczas której został ranny. Następnie krótko był rotmistrzem husarskim, wkrótce jednak, może ze względu na redukcję armii, na dłuższy czas porzucił służbę

\footnotetext{
51 Akta sejmikowe województwa lubelskiego 1572-1632, oprac. H. Gmiterek, Lublin 2016, s. 96, 114, 215, 279, 313; Rejestr poborowy województwa lubelskiego: powiat lubelski i urzędowski z r. 1626, ziemia tukowska z r. 1620, oprac. J. Kolasa i K. Schuster, Wrocław 1957, s. 8, 105, 113, 130.

${ }^{52}$ Rejestr poborowy województwa lubelskiego, s. 113 wymienia niejakiego Andrzeja Sierakowskiego, potomka Wojciecha, nie wiadomo jednak, czy można go utożsamiać z Andrzejem, późniejszym pisarzem polnym i ojcem Jana Andrzeja.
} 
wojskową. W kolejnych latach zapewne bardziej zajmowały go sprawy rodzinne i majątkowe. Wiadomo, że 14 X 1638 r. poślubił w Lublinie Katarzynę z Ostrorogów, córkę Jana, wojewody poznańskiego. Ten niewątpliwie prestiżowy mariaż przyniósł Sierakowskiemu nowe nabytki (m.in. wieś Strzeszkowice) ${ }^{53}$. Wkrótce potem Sierakowski wraz z żoną otrzymał od Władysława IV dzierżawę wójtostwa we Wrotkowie. W stosownym akcie monarcha wskazywał na rycerskie zasługi Sierakowskiego w wojnach ze Szwecją i z Moskwą. W 1645 r. zapewne po raz pierwszy Andrzej posłował na sejm jako reprezentant obywateli ziemi chełmskiej ${ }^{54}$. W tym też czasie Sierakowski powrócił do służby wojskowej. W styczniu 1644 r. u boku hetmana Stanisława Koniecpolskiego wziął udział w zwycięskiej batalii z Tatarami pod Ochmatowem. Walczył potem przeciw powstaniu kozackiemu Bohdana Chmielnickiego. We wrześniu $1648 \mathrm{r}$. w szeregach bełskiego pospolitego ruszenia uczestniczył w niechlubnej kampanii piławieckiej. W końcu tego roku był wśród elektorów obieranego właśnie Jana Kazimierza, zaciągał również nowe oddziały do odbudowywanej armii. Wczesną wiosną 1649 r. powołano go, raczej nieoczekiwanie, na urząd pisarza polnego koronnego, co wprowadziło go do kręgu najwyższych rangą dowódców wojskowych. W lipcu tego roku, stojąc na czele rot husarii, rajtarii i dragonii, bronił z innymi Zbaraża. Poprowadził wówczas duży podjazd wysłany w celu rozpoznania zamiarów przeciwnika. Operacja nie przyniosła większego powodzenia, o co obwiniano także Sierakowskiego. 23 VII podczas kolejnego ciężkiego bombardowania twierdzy Andrzej został poważnie postrzelony, co niewątpliwie pociągnęło za sobą śmierć pisarza 26 VII 1649 r. w zbaraskim obozie ${ }^{55}$.

Jan Andrzej Sierakowski był synem Andrzeja i Katarzyny z Ostrorogów. Nie wiemy, kiedy się urodził i jak przebiegały wczesne lata jego życia. Tak niepewna podstawa, jak znany nam czas ukończenia przez Jana Andrzeja nauki szkolnej (1664 r.) i późniejszego nieco przejęcia pełnej władzy nad rodzinnym majątkiem (1668 r.), pozwala jedynie na spekulacje, że urodził się zapewne koło połowy lat 40.

${ }^{53}$ M. Nagielski, Sierakowski Andrzej, PSB. T. 37, 1996, s. 256-257; Biblioteka Czartoryskich w Krakowie (dalej BCzart.), sygn. 390, s. 412; Rejestr poborowy województwa lubelskiego, s. 61, 141; A. S. Radziwiłł, Pamiętnik o dziejach $w$ Polsce. T. 1, oprac. A. Przyboś i R. Żelewski, Warszawa 1980, s. 340 .

${ }^{54}$ Oblata nadania Władysława IV, Warszawa, 1 XII 1639, Archiwum Państwowe w Lublinie (dalej APL), Księgi grodzkie lubelskie (dalej Kgl), Relacje, sygn. 69, k. 1029v-1030v; J. Ternes, Sejmik chełmski za Wazów (1587-1668), Lublin 2004, s. 166, 168; Akta sejmikowe ziemi chełmskiej 1572-1668, oprac. W. Bondyra, H. Gmiterek, J. Ternes, Lublin 2013, s. 250.

${ }_{55}$ M. Nagielski, dz. cyt.; A. S. Radziwiłł, dz. cyt. T. 3, s. 127, 214, 218; Relacje wojenne z pierwszych lat walk polsko-kozackich powstania Bohdana Chmielnickiego okresu „Ogniem i mieczem” (1648-1651), oprac. M. Nagielski, Warszawa 1999, s. 127, 133, 135, 140, 169, 177. 
XVII w., może nawet na krótko przed wybuchem powstania na Ukrainie. Niewiele wiadomo o jego rodzeństwie. Pewne jest tylko, że miał starszą, najpewniej, siostrę Annę Zofię, która w 1656 r. została wydana za mąż za Tomasza Ulińskiego, podstolego podolskiego i rotmistrza, z którym miała potomstwo. Po śmierci męża, po 1662 r. poślubiła Piotra Potempskiego (Potępskiego), wojskiego trembowelskiego, z którym także miała dzieci ${ }^{56}$.

W aktach publicznych Jan Andrzej pojawił się wcześnie, już we wrześniu $1651 \mathrm{r}$., $\mathrm{w}$ oblatowanym $\mathrm{w}$ grodzie lubelskim królewskim akcie potwierdzającym prawa Katarzyny i Jana Sierakowskich, „matri cum filio”, do dzierżawy Wrotkowa ${ }^{57}$. Przyszły kasztelan niewątpliwie wychowywał się przede wszystkim u boku matki, pewnie we Wrotkowie lub w Wierzchowinach, głównych majątkach rodziny, rzadziej zapewne w bełskim Żabczu, położonym przecież na obszarze wciąż zagrożonym wojną. Chyba w końcowych latach „potopu” chłopiec rozpoczął naukę szkolną. Nie wiemy gdzie, chociaż późniejsze, dosyć intensywne powiązania Sierakowskiego z lubelskimi jezuitami zdają się wskazywać na tamtejsze kolegium zakonu. Po ukończeniu edukacji w 1664 r., w warunkach rozpalającej się właśnie wojny domowej w Rzeczypospolitej, w 1665 r. zaciągnął się, jeszcze bez zbrojnego pocztu, do pancernej, a wkrótce potem husarskiej chorągwi Stanisława Jabłonowskiego, wojewody ruskiego ${ }^{58}$. Swego rotmistrza sam Sierakowski nazywał „bratem moim”, bowiem matki wojewody i Jana Andrzeja były rodzonymi siostrami. Sądzić należy, że owe bliskie związki rodzinne z niezwykle wpływowym w całej epoce rządów Jana Sobieskiego hetmanem wielkim Jabłonowskim bardzo znacząco oddziaływały na wszystkie późniejsze etapy wojskowej i cywilnej kariery Sierakowskiego. Już w 1668 r. został chorążym roty pancernej Jabłonowskiego, zapewne uczestniczył również w większości operacji militarnych w tym okresie. W 1669 r. uwikłał się w długotrwały proces sądowy wywołany krwawą awanturą na przedmieściu krakowskim w Lublinie, do której doszło w połowie grudnia tego roku. W jej trakcie Sierakowski i Jan Sobieszczański, także towarzysz roty Jabłonowskiego, poważnie „posiekli” łowczego chełmskiego Jana Krzewskiego i Michała Wilkońskiego,

\footnotetext{
${ }^{56}$ Skrypt Ulińskich, Wierzchowiny, 4 XII 1656, potwierdzający wypłatę intercyzy „w klejnociech, złocie i srebrze”: Kgl, Relacje, sygn. 88, k. 82-82v. Zob. także: tamże, sygn. 104, k. 304-304v, 1485; sygn. 128, k. 291.

57 Akt króla Jana Kazimierza dla Sierakowskich, Lublin, 19 IX 1651, zob. Kgl, Relacje, sygn. 86, k. 449v-451v.

${ }^{58}$ Te i kolejne informacje biograficzne głównie na podstawie: E. Janas, dz. cyt. oraz raptularza Sierakowskiego.
} 
towarzyszy chorągwi Jana Sobieskiego, oraz nieznanego bliżej Bernarda Szpota ${ }^{59}$. Sprawa, zakończona w końcu ugodą, jak zanotował sam Jan Andrzej, „znacznie mię kosztowała”. Od początku lat 70. przyszły kasztelan, ciągle pozostający w służbie, był bardzo czynny w bełskim samorządzie szlacheckim, wielokrotnie pełnił różne funkcje, $w$ tym prestiżowe i liczące się w karierze, marszałka sejmików oraz posła na sejmy (po raz pierwszy w 1672 r.) ${ }^{60}$. Wtedy też zapewne uzyskał swą pierwszą nominację na urząd ziemski - został stolnikiem bełskim, następnie sięgnął po godność podkomorzego bełskiego ( 1685 r.) i wreszcie po kasztelanię bełską $(1687 \text { r. })^{61}$.

Po zakończeniu kampanii chocimskiej w 1673 r. Sierakowski najprawdopodobniej zawiesił na krótko służbę wojskową. Do armii powrócił jednak już w 1674 r., kiedy został rotmistrzem chorągwi pancernej - pozostał nim zresztą do końca życia. Dosyć regularnie uczestniczył w licznych kampaniach i operacjach militarnych. Kilkakrotnie pełnił funkcję regimentarza, dowodząc większymi partiami wojska $(1683,1685,1693 / 94$ r.), często również reprezentował interesy żołnierzy w komisjach hibernowych i wojskowych. W 1697 r. był komisarzem sejmowym prowadzącym rokowania ze zbuntowanym wojskiem. Trudno widzieć w nim wybitnego dowódcę, ale znaczniejszą rolę, jako zasłużony oficer, odegrał w 1683 r. nie wziął wprawdzie udziału w głośnej odsieczy wiedeńskiej, ale ze sporym powodzeniem operował na czele kilkunastu chorągwi jazdy w Naddniestrzu, pilnował granicy, blokował turecką załogę Kamieńca Podolskiego i zwalczał działające tam czambuły tatarskie. Większą rolę odegrał również podczas kampanii mołdawskiej W $1691 \mathrm{r}$.

W 1673 r. poślubił Katarzynę Stadnicką, córkę Wiktoryna, kasztelana lubaczowskiego, z rodu zamożnego i liczącego się na Rusi Czerwonej. Para doczekała się aż jedenaściorga potomstwa, z których większość zmarła jednak w pierwszych latach życia. Wieku dorosłego doczekali jedynie syn Józef oraz córki Izabela i Marianna. Po śmierci żony (1689 r.), posiadając poparcie pary królewskiej, bez powodzenia starał się o rękę Katarzyny Korniaktówny, protegowanej prymasa

\footnotetext{
${ }^{59}$ Kgl, Relacje, sygn. 95, k. 1115-117v; sygn. 96, k. 121v-123, 201v-202v, 334-336, 919v.

${ }^{60}$ Biblioteka Ossolińskich we Wrocławiu, Akta sejmiku bełskiego, sygn. 15964, cz. 1, m.in. s. 829, 839; cZ. 2, s. 13, 23, 199.

${ }^{61}$ Urzędnicy województwa betskiego i ziemi chetmskiej XIV-XVIII wieku. Spisy, oprac. H. Gmiterek i R. Szczygieł, Kórnik 1992, nr 74, 191, 343.
} 
Michała Radziejowskiego ${ }^{62}$. Dopiero około 1697 r., zatem na krótko przed śmiercią, poślubił Ludwikę z Dąmbskich, wdowę po Franciszku Denhoffie, łowczym litewskim.

Oryginał rękopiśmienny raptularza Sierakowskiego znajduje się obecnie w księdze zatytułowanej „Ex connotatis Joannis Sierakowski castellani bełzensis” przechowywanej w Bibliotece Czartoryskich w Krakowie (sygn. 862, s. 45-55). Dodać trzeba, iż w księdze tej umieszczony jest także niepublikowany tutaj tekst Sierakowskiego „Konnotata różnych transakcyjej w Polszcze” (BCzart., sygn. 862, s. 1-12). Księga ta zapewne do schyłku XVIII w. pozostawała w posiadaniu rodziny, następnie trafiła do zbiorów poryckich Tadeusza Czackiego, po czym w $1818 \mathrm{r}$. drogą zakupu przejęli ją Czartoryscy. Rękopis pisany jest jedną ręką, na ogół bez dopisków czy uzupełnień. Poniższy tekst raptularza przygotowany został zgodnie z zasadami określonymi w stosownej instrukcji wydawniczej ${ }^{63}$.

\section{Summary}

\section{Jan Andrzej Sierakowski and His Private Diaries}

The main part of this article is the edition of a short diary from the second part of seventeenth century which undoubtedly belongs to the genre of family memoirs so popular in the nobility writings of the seventeenth and eighteenth century. The text, written by Jan Andrzej Sierakowski (died in 1698), is a factual and concise history of events from 1664-1697; first of all it concerns private and family history but also pertains to the public activity of the author and his numerous mainly property) transactions. The diary seems an interesting item of evidence of the nobility's everyday life. The edition is preceded by a short history of Sierakowski family, especially regarding the author of the text.

KEYwords: family diaries - seventeenth century, Jan Andrzej Sierakowski, Polish history in the seventeenth century.

${ }^{62}$ K. Sarnecki, Pamiętniki z czasów Jana Sobieskiego. T. 1, oprac. J. Woliński, Wrocław 2004, s. $102-103,135$.

${ }^{63}$ Instrukcja wydawnicza dla źródeł historycznych od XVI do połowy XIX wieku, red. K. Lepszy, Wrocław 1953. 


\section{Tekst źródłowy}

Org. rkps: Biblioteka Czartoryskich w Krakowie, sygn. 862, s. 45-55.

[s. 45] Pewne konnotata prywatne domowych traknsakcyji moich.

Annus 1664. Wyszedłem ze szkół, skończywszy filozofią.

Annus 1665. Na wojnie domowej między królem jmścią Kazimierzem a jmp. Lubomirskim ${ }^{1}$ toczącej się byłem z bratem moim jmp. Jabłonowskim wojewodą ruskim², alem pocztu pod chorągwią jeszcze nie miał.

Annus 1666. Podprowadziłem poczet pod pancerną chorągiew jmp. wojewody ruskiego gdzie porucznikował p. Bliskowski a chorągiew nosił p. Zagurski ${ }^{3}$.

Annus 1667. Nihil notabile w tym roku.

Annus 1668. Dał mi nosić chorągiew swoją pancerną jmp. Jabłonowski wojewoda ruski. Tegoż roku matka dobrodziejka moja $\mathrm{z}$ afektu swego ustąpiła mi wszystkich dóbr, zostawiwszy sobie Zochcin pod Opatowem.

Annus 1669. Zastawiłem Wirzchowinę $e^{4}$ jmp. Prokopowi Szornelowi we fl. 25000. Tegoż roku padło na mię nieszczęście posieczenia p. Krzewskiego, p. Wilkuńskiego i Szpota, która sprawa wprzód w grodzie lubelskim a potym w trybunale traktowana znacznie mię kosztowała. In decembre poszła chorągiew jmp. wojewody ruskiego do Schowy ${ }^{5}$ usarzyć się. Z p. Szornelem tego roku in decembre traktowałem, ale mu się in futuro anno od Trzech Królów [6 I] possesyja Wirzchowiny zaczęła.

Anno 1670. Eliberowałem Strzeszkowice ${ }^{6}$ zastawione u jmp. Rzeczyckiego, a że moja siostra rodzona jmp. Potępska ${ }^{7}$ trzymała Żabcze ${ }^{8}$ cum attinentiis w województwie bełskim we fl. 30000 sobie respektu posagu [s. 46] należących, poszedłem z nią per commutationem uczyniwszy jej donacią na Strzeszkowice i oddałem jej jeszcze fl. $2500 \mathrm{z}$ znaczną moją krzywdą. Odebrałem tedy in possessionem meam Żabcze w tym roku die 13 julii.

${ }^{1}$ Jerzy Sebastian Lubomirski, marszałek wielki koronny.

${ }^{2}$ Stanisław Jabłonowski.

${ }^{3}$ Zbigniew Bliskowski, zapewne Stanisław Zagurski (Zagórski), w 1662 r. deputat chorągwi Jabłonowskiego.

${ }^{4}$ Obecnie Wierzchowiny, wieś koło Chełma i Krasnegostawu.

${ }^{5}$ Wschowa w Wielkopolsce.

${ }^{6}$ Wieś koło Kraśnika.

${ }^{7}$ Lub Potempska.

${ }^{8}$ Wieś koło Bełza. 
Annus 1671. Powróciłem z Ukrainy od chorągwi, a powracając do krztu trzymałem jmp. wojewodzie ruskiemu syna Aleksandra w Podkamieniu ${ }^{1}$ z jm. Panną Słuszczanką podskarbianką litewską ${ }^{2}$, który syn jm. potym został starostą buskim, daj Boże i czym wyższym.

Annus 1672. Stanąłem posłem z Bełza na sejm warszawski ${ }^{3}$. Poczet sprowadziłem spod chorągwi.

Annus 1673. Ożeniłem się z jm. panną Katarzyną Stadnicką na ten czas kasztelanką lubaczowską w Białobokach pod Kańczugą w ostatni wtorek mięsopustny [14 II]. Tegoż roku anticipative przed moim ożenieniem puściłem Żabcze cum attinentiis $\mathrm{w}$ arendę $\mathrm{p}$. Widzowskiemu, 30 aprilis uczyniłem przenosiny do Wrotkowa żony mojej.

Annus 1674. Zgodziłem się z p. Widzowskim żeby mi ustąpił Żabcza i wróciłem mu dane na arendę pieniądze. Wtedyż pp. Sobiesczańskich i p. Siwkowskiego na Siebieczowie ${ }^{4}$ certarum sorti także i p. Boguckiego na Bezejowie ${ }^{5}$ certam sortis obligatorios possessores summą posażną pospłacałem. 13 martii matka i dobrodziejka moja umarła w Opatowie, tamże pochowana u oo. Bernardynów 21 maj. Zległa pierwszym połogiem żona moja w Białobokach 18 aprilis, ale nie barzo szczęśliwie bo chłopczyk który się urodził vix ab obstetrice baptisatus eodem instant umarł, pochowany w ostrowskim kościele blisko Białobok. 9 decembris umarła rodzona siostra moja jmp. Potępska w Bielinach ${ }^{6}$. Dano mi chorągiew pancerną po jmp. Domaszowskim staroście na ten czas łukowskim ${ }^{7}$.

Annus 1675. Urodziła się córka Teresa 15 martii w Zapałowie ${ }^{8}$, in junio w tym roku ciężko i długo chorowałem.

Annus 1676. Urodziła się nam córka Izabella w Wrotkowie 14 decembris.

Annus 1677 . Zbyłem prawa mego zastawnego na Zochcinie ${ }^{9}$, na którym miałem fl. 9000 jmp. Kurdwanowskiemu podwojewodzemu sendomirskiemu ${ }^{10}$. Od niedzieli przewodniej [22 IV] puściłem w trzyletnią arendę Żabcze cum attinentiis

\footnotetext{
1 Miasteczko koło Brodów.

2 Zapewne Konstancja Słuszczanka.

3 Posłem na sejm z sejmiku bełskiego Sierakowski został obrany 27 IV 1672 r. (Biblioteka Ossolińskich we Wrocławiu, sygn. 15964, s. 829).

4 Wieś koło Bełza.

5 Wieś koło Bełza.

${ }^{6}$ Wieś koło Niska.

${ }^{7}$ Kazimierz Widlica Domaszewski.

8 Wieś koło Bełza.

9 Wieś koło Lubaczowa.

10 Zapewne Jan Stanisław Kurdwanowski.
} 
jmp. Mikołajowi Jabłońskiemu, a złączywszy summy i z posażnej przyłożywszy, wykupiłem Wirzchowinę, która była w zastawie u jmp. Prokopa Szornela.

Annus 1678. Umarła nam córka Teresa w Białobokach, która się chowała przy prababce swojej jmp. Tomisławskiej. Eodem anno urodził się nam syn w Białobokach, danu mu imię Stanisław.

Annus 1679. Umarł jmp. Tomisławski dziad żony mojej w Białobokach 3 maii pochowany w Jarosławiu w kolegium jezuickim. 2 novembris to jest w sam dzień zaduszny urodził się nam syn w Wrotkowie, dano mu imię Franciszek.

Annus 1680. Wyszło mi Żabcze z arendy. Zastawiłem Siebieczów jmp. Trębińskiemu ${ }^{1}$ pisarzowi ziem. bełskiemu we fl. 15000 . In aprilis chodziłem i z żoną do Gdańska wodą. 16 decembris urodziła się nam córka w Wirzchowinie, dano jej imię Anna.

[s. 47] Anno 1681. In junii nawiedził nas Pan Bóg żalem pobrawszy nam dziatki w Wirzchowinie, $\mathrm{z}$ których 9 junii umarła Anna, 16 eiusdem umarł Stanisław. 22 eiusdem umarł Franciszek. Pochowano wszystkich w kościele chłaniowskim $^{2} \mathrm{w}$ grobie pp. Jasińskich.

Anno 1682. Arendowałem Wirzchowinę na trzy lata jmp. Janowi Pajewskiemu, u jmści pani Chamcowej wziąłem w prowizją fl. 12000 a wykupiłem Siebieczów u jmp. Trębińskiego. 23 ianuarii w Mołodyczu pod Jarosławiem umarła jmp. Jadwiga Tomisławska babka żony mojej, pochowana w Jarosławiu w kolegium oo. Jezuitów. Eodem Anno w Niemirowie ${ }^{3} 9$ maii urodził się nam syn, któremu na krzście ś. dano imię Józef. 16 decembris był sejmik w Bełzie przedsejmowy, z którego stanąłem na sejm posłem.

Anno 1683. Oddałem jmp. Chamcowej z pomienionej summy fl. 3000 a zostałem winien fl. 9000, od których mam płacić prowizją. 19 ianuarii wyjechałem z Żabcza na sejm do Warszawy. 28 aprilis powróciłem nazad z sejmu. 4 augusti wyjechałem z Żabcza do obozu pod Zawałów ${ }^{4}$ odebrawszy ordynans żebym za wyjściem wojsk pod Wiedeń został z szesnastą chorągwi i z Kozakami pro securitate kraju od Kamieńca. 8 decembris powróciłem z wojny do Żabcza nieźle gościwszy na tej kampanijej.

\footnotetext{
1 Kasper Trembiński.

2 Chłaniów, w. koło Krasnegostawu.

3 Miasteczko koło Rawy Ruskiej.

4 Miasteczko pod Podhajcami.
} 
Anno 1684. 14 martii w Wrotkowie urodził się nam syn, dano mu imię na krzście ś. Wiktoryn. 25 aprilis w Niemirowie umarł ojciec żony mojej jmp. kasztelan przemyski ${ }^{1}$. Byłem dystrybutorem od wojska do hiberny.

Anno 1685. In februario zostałem podkomorzym bełskim. 4 maii pogorzałem srodze w Żabczu. 7 junii dano mi komendę wojska generalną do powrotu z Warszawy jmp. hetmana wiel. koronnego ${ }^{2} .21$ septembris odwieźliśmy Izabellę córkę naszą do klasztoru warszawskiego. [s. 48] 27 novembris urodził się nam syn Antoni w Wrotkowie. W tym roku siostrzeńcy moi ichmpp. Ulińscy przedali Ulinę cum attinentiis jmp. Zamoyskiemu podskarbiemu wiel. koronnemu ${ }^{3}$.

Anno 1686. Część którą trzymał w Żabczu jmp. Jagiełowicz we fl. 2600 puściłem jmp. Aksakowej we fl. 4000 a dwa u tejże wziąłem w prowizyję, z której summy oddałem jmp. Chamcowej fl. 30oo. Już jej tedy tylko winienem fl. 6ooo. Kiedym był na wojnie w Wołoszech umarło mi dwóch synów Wiktoryn i Antoni. Powróciwszy z wojny byłem do hiberny dystrybutorem.

Anno 1687. Część sobie zastawną w Żabczu jmp. Aksakowa za konsensem moim spuściła jmp. Ochockiemu. Wirzchowina o środopościu wyszła mi $z$ arendy i odebrałem ją na się. Od tegoż śródpościa wziąłem w prowizyją do lat trzech piąci tysięcy. Kupiłem na ś. Jan [26 VI] u jmp. Lipskiego stolnika kijowskiego ${ }^{4}$ królewszczyznę Brusno ${ }^{5}$, dałem za nią fl. 19500. W tęż kupno włożyłem summę od p. Grzymały. 8 augusti w Wrotkowie urodziła się nam córka, na krzcie ś. dano jej imię Marianna. 16 decembris na sejmiku bełskim stanąłem posłem do Grodna.

Anno 1688. Wziąwszy u jmp. Izbińskiej summy należącej sukcesorom p. Trzcińskiego i Lesieckiego fl. 7500 oddałem resztę długu jmp. Chamcowej fl. 6000 i kwitowałem się de plano, lubo p. Rączka ${ }^{6}$ rejent na ten czas grodzki bełski, człowiek temulentus i pijanica pokawił był w kwicie, ale się to poprawiło. In Julio wziąłem prowizyją fl. 2000 summy kościołowi płoneckiemu należącej. 16 septembris w Niemirowie urodził się nam syn, dano mu na krzcie ś. imię Michał. [s. 49] In martio w Grodnie dano mi kasztelanię bełską po śmierci jmp. Jana Myszkowskiego. 6 maii ruszyłem się wodą do Gdańska z Kazimierza. In maii umarła jmp. Rostworowska rodzona żony mojej w Bochotnicy.

\footnotetext{
${ }^{1}$ Wiktoryn Stadnicki.

${ }^{2}$ Stanisław Jabłonowski.

3 Marcin Zamoyski.

${ }^{4}$ Samuel Lipski.

${ }^{5}$ Wieś koło Lubaczowa.

${ }^{6}$ Zapewne Jan Rączka.
} 
Anno 1689. Puściłem w trzyletnią arendowną posesyję Siebieczów jmp. Potockiemu, wziąłem od niego ad rationem fl. 7500.18 aprilis ruszywszy się z zbożem do Gdańska powróciłem do Wirzchowiny 21 maii. 29 junii kochana żona moja umarła w Warszawie. 28 julii do inszych pieniędzy którem miał na pogrzeb żony mojej zaciągnąłem w prowizyją u jmp. Jacka Iwanickiego fl. 5000. 5 septembris termin pogrzebu kochanej żony mojej u oo. Jezuitów w Lublinie.

Anno 1690. Na Trzy Króle przedałem królewszczyznę Brusno jmp. Kurdwanowskiemu za fl. 2300o, z których oddałem jmp. Swiżawskiemu co był niedotrzymał na arendzie brusińskiej fl. 6533 item jmp. Lesieckiemu pro sorte dzieci jego należących zostawiłem przy jmp. Kurdwanowskim fl. 6000, jmp. Maciejowi Grzymale oddałem cum provisione fl. 5500 i inne długi popłaciłem. 16 ianuarius wyjechałem do Warszawy na sejm. 7 maii powróciłem z Warszawy do Żabcza. Na tym sejmie w samą Wielką Noc [26 marca] oddałem starszą córkę moją Izabellę do fraucymeru górnego królowej jm. Szarańcza sroga w tym roku panowała. Byłem w obozie a potym dystrybutorem od wojska do hiberny.

Anno 1691. Wziąłem od Trzech Królów w prowizyją u jmp. Żelichockiego fl. 400o. Od tychże Trzech Królów puściłem Żabcze w trzyletnią arendę jmp. Mikołajowi Jabłońskiemu zostawiwszy sobie zamek i część pewną pańszczyzny. [s. 50] Z tych summ niektóre długi poznosiłem, osobliwie część w Bezejowie zastawną jmp. Jerzemu Sobieszczańskiemu we fl. 4500 wykupiłem. Od ś. Jana wziąłem na drogę obozową u jmp. Świeżawskiego fl. 2000. Wtedyż na tęż drogę u jmp. Jacka Iwanickiego fl. 1000. Die 26 augusti wyjechałem z Wirzchowiny do obozu a nie zastawszy króla jm. pod Śniatynem miałem komendę nad pozostałemi, z któremi jako i z prowiantem ordynowanym z Śniatyna przyszedłem do króla jm. do Wołoch pod Kunczeste ${ }^{1} \mathrm{z}$ wielkim moim kłopotem i kosztem.

Anno 1692. W post wielki wstąpiwszy zawiozłem Józefa syna mego do szkół lubelskich. Od Trzech Królów wziąłem w prowizyją u jmp. Wojciecha Potockiego fl. 1000o. Michałek z Marysią ospę odbyli. Zastawiłem część w Bezejowie od jmp Jerzego Sobieszczańskiego wykupioną jmp. Michałowi Jabłońskiemu we fl. 6000. $\mathrm{Z}$ tej summy oddałem jmp. Zalchockiemu fl. 40oo, za ostatek wina kupiono mi w Jaśliskach ${ }^{2}$. Wyszła mi arenda siebieczowska. Znowu od środopościa wziąłem u jmp. Zalichockiego w prowizyją tych fl. 400o, którem był oddał. Z tych dałem córce mojej Izabelli fl. 1000. Kupiłem we Lwowie konia gniadego tureckiego do stada. Die 1 maii wziąłem w prowizyją u p. Jaślikowskiej fl. 2000. Jmp. Świeżaw-

\footnotetext{
${ }^{1}$ Pisownia nazwy niejasna. Zapewne chodzi o miejscowość Concesci koło Neamt w Mołdawii

${ }^{2}$ Wieś koło Sanoka.
} 
skiemu oddałem tak rok pożyczone fl. 200o. Od ś. Jana wziąłem w prowizyją u jmp. Michała Jabłońskiego fl. 1500, z tych oddałem jmp. Jackowi Iwanickiemu tak rok pożyczony fl. 1000. In septembre pomarli ichmpp. Ulińscy oba siostrzeńcy moi. In decembre otrzymałem po śmierci jmp. Myszkowskiego stolnika bełskiego ${ }^{1}$ starostwo tyszowieckie z łaski JKM w Żółkwi. Odebrałem ad rationem zasług na pieszą chorągiew moją w ziemi sanockiej fl. 60oo. W tymże roku w ćwierci nowembrowej zaciągnąłem na porucznikostwo [s. 51] pancerne jmp. Walentego Dąbskiego.

Annus 1693. Byłem w obozie, który stał pod Buczaczem. Puściłem od Trzech Królów zastawą ad triennium in summa fl. 5000 jmp. Jackowi Iwanickiemu część pewną w Klątwach wsi do starostwa tyszowieckiego należącej cum evictione na dobrach dziedzicznych. Wziąłem w prowizyją u jmp. Kosakowskiego fl. 2000. Sejm in decembre złożony dla słabego zdrowia króla jm.translapsowany, podczas którego w niebytności hetmanów jam miał mieć generalną wojska komendę, i jużem miał ordynans.

Anno 1694. Od Trzech Królów ad biennium zastawiłem pewne części w Żabczu i Bezejowie jmp. Radeckiej we fl. 1600o, a fl. 8000 wziąłem w prowizyją. Z tych jmp. Michałowi Jabłońskiemu wróciłem z części bezejowskiej fl. 6000 i niektóre praetensie ratione arendy żabieckiej, jako i fl. 1500 pożyczanych wypłaciłem a Żabcze na się otrzymałem. Także i insze długi jako to p. Jaślikowskiej fl. 1000 zapłaciłem, drugi fl. 1000 jest jeszcze przy mnie. Arendowałem do roku jednego Siebieczów jmp. Wojciechowi Potockiemu, p. Woroniczowi dług winny zapłaciłem. Od ś. Jana do Trzech Królów wziąłem w prowizyją u jmp. Michała Brzezickiego na drogę obozową fl. 4000. (--)a

[s. 54] Annus 1695. Jmp. Wojciechowi Potockiemu z summy dziesiątka tysięcy którą miał u mnie w prowizyjej oddałem na zniesienie jmp. Korytków pod czas Trzech Króli fl. 4500. In reliquo na rok Siebieczów temuż arendowałem. Od Trzech Królów wziąłem w prowizyją do roku u jmks. Raczkowskiego proboszcza grabowieckiego fl. 5000, zaraz naprzód oddałem prowizyją. Wziąłem pozostałych sirot po nieboszczyku. p. Jerzym Sobieszczańskim summy zł. 2000 a trzeci tysiąc ma mi oddać jmp. Jan Niedźwiecki tymże dzieciom należący na przyszłe Trzy Króle. Oddałem jmp. Brzezickiemu z summy fl. 4000 złotych pięćset reliqum mam oddać na przyszłe Trzy Króle. W obozie tego roku nie byłem. W Kamieńcu było wielkie powietrze. P. Jaślikowskiej ad rationem dałem fl. 100.

a Na s. 52-53 fragment tekstu opuszczony, niezwiązany z raptularzem - życzenia króla i królowej dla córki Teresy Kunegundy z okazji jej zamążpójścia 13 XI 1694 r.

${ }^{1}$ Adam Kazimierz Myszkowski. 
Annus 1696. Summę piąciu tysięcy na Brusnie zostawioną dzieci jmp. Lesieckiego wziąłem do rąk moich puściwszy mu we trzech tysięcy część pewną we wsi Kulinie w starostwie tyszowieckim leżącej a dwa tysiące w prowizyją, od których na zupełny rok przyszły zapłaciłem mu ją. Arendowałem Siebieczów na trzy lata jmp. Wojciechowi Potockiemu za fl. 80oo, którą summą in reliquo długu jego co miał u mnie, zbyłem go, ostatek on mnie dodał i jużem ja mu nic niewinien. Oddałem jmks. Raczkowskiemu fl. 2000. Restat mu u mnie fl. 3000. Jmp. Jackowi Iwanickiemu z tych dwóch tysięcy co miał u mnie w prowizyjej oddałem fl.100o a drugi przyczyniłem do tamtych piąci tysięcy i puściłem mu całe Klątwy w zastaw rocznym kontraktem we fl. 6000. 29 januarius dałem p. Jaślikowskiej względem prowizyjej od tysiąca złotych fl. 200. Jak jej dodam fl. 130 będzie miała zupełną prowizyją aż ad diem 1 maii w tym roku. Dałem zupełną prowizyją p. Trzemeskiej od summy fl. 750. [s. 55] Com był wziął u jmp. Piaseckiej, jeszcze wdową Ulińską będącej na wygodę chorągwi mojej fl. 3000 i zapisałem jej w grodzie grabowieckim. Wypłaciłem, item jenom winien dodać fl. 160 gr. 16. Na te trzy tysiące mam kwitek roczny, ale mię jej mść, z zapisu w grodzie grabowieckim kwitować powinna jak weźmie resztę fl. 160, gr. 16. Z summy fl. 2000 na prowizyją jmp. Kossakowskiego wziętej oddałem pomienionemu jm. fl. 200. Ma tedy mnie summy fl. 1800 i prowizyją za ten czas zupełną wypłaciłem, krom tego tenże jmp. Kossakowski ma u mnie fl. 1000, w którym część pewną trzyma w Perespie. Circa finem augusti jadąc do Warszawy na konwokacyją wziąłem w prowyzyją u jmp. Seweryna Jasińskiego fl. 1000 per decem centum.

Annus 1697. Od Trzech Królów wziąłem w prowizyją u jmp. Jacka Iwanickiego per decem centum fl. 7000, zaraz ad rationem prowizyjej odtrąciłem fl. 500 reliquum mam dać za kwitem ręcznym. Z reszty fl., 3000 jmks. Raczkowskiemu winnej oddałem temuż jm. fl. 1000. Nie winienem tylko fl. 2000 i od tych wyliczyłem zaraz prowizyjej fl. 200. Dałem na część Chłaniowa tę co jmp. Kurowicz trzymał za konsensem pisanym jmp. Czyżowej stolnikowej wileńskiej ${ }^{1}$ według kontraktu, który on trzymał fl. 4000 a za praetensie które mu condescensio officiosa przysądziła fl. 1000 insuper za kartą dałem jmp. stolnikowej fl. 400 jmp. Zembockiemu zięciowi jej za kartą jego fl. 300, co wszystko efficit fl. 5800. Od Trzech Królów w tym roku arendowałem starostwo tyszowieckie wyjąwszy sobie Perespę jmp. Kurowiczowi za fl. 1400o. Z tej sumy wykupiłem jmp. Iwanickiego z Klątew, a rodzonej siostry jego posagu trzy tysiące zostawiłem przy sobie aż do zamęścia jej.

\footnotetext{
1 Anna Bądzyńska, żona Jana Kazimierza Czyża, stolnika wileńskiego.
} 